\title{
CAUSES AND EFFECTS OF WOMAN RURAL-URBAN MIGRATION - FIELD STUDY AMONGST FEMALE STREET FOOD VENDORS IN TANGERANG-INDONESIA AND HAT YAI-THAILAND
}

Dionisius Yusuf ${ }^{1}$, MSc.; Barbara Freytag-Leyer ${ }^{2}$, Dr.oec.troph./Prof. i.R. ${ }^{1}$ University of Kassel; ${ }^{2}$ Fulda University of Applied Sciences, Germany

\begin{abstract}
Rural-urban movements from poor rural areas to rich urban areas have been the dominant form of migration. A sharp increase in rural-urban migration is stated in recent years in Tangerang, Indonesia, and Hat Yai, Thailand. One of the important changes in internal movements in Indonesia and Thailand have been the rise in the participation of women in migration streams that were previously dominated by men. For studying the causes and effects of women migration, 200 female migrant vendors in Tangerang and 96 in Hat Yai were surveyed, 20 biographical interviews were recorded. Important differences in both study areas were in the proximity of the urban centres. In Tangerang, long-distance migration dominated, in contrast to the shortdistance migration in Hat Yai. The start of the migration was slightly shorter in Hat Yai. The influencing decision makers showed wide differences. In Tangerang, the influence of the male-dominated society was strong, and husbands were the most important decision maker, while in Hat Yai females' own decisions dominated. The information sources for migration were families, relatives and friends, whereas mass media played a minor role. The pull and push factors for migration differed in both study areas. Prospects were namely at first place in both study areas, but in different percentages. Remittances to the families were reported from a few number. The rural-urban migration and working as street food vendors had positive effects for the women, their families and relatives, but the agricultural production in rural areas can be hampered through the decrease of younger population.
\end{abstract}

Key words: rural-urban migration, female street food vendors, Tangerang Indonesia, Hat Yai Thailand, feminization of internal migration.

JEL code: D19, E 29, G 59, J 69, N35

\section{Introduction}

Over the last decade, attention has been given to international migration. More recently, internal migration in general and rural-urban migration, in particular, was viewed favourably in the literature. Several studies indicate that internal migration is a driver of growth and an important route out of poverty with significant positive impacts on people's livelihoods and well-being (Murrugarra E. et al., 2011; Hossain E., 2001; Siddiqui T., 2003; Sukamdi Mujahid G., 2015).

Internal migrants in Indonesia constitute a significant population. Nearly 9.8 million individuals were estimated to be temporary internal migrants in 2010 against merely 450.601 people migrating internationally for work in 2012 (Ananta A. and Arifin E. N., 2014). In Thailand, according to the 2010 Thailand Population and Housing Census, 8.3\% of the Thai population had migrated internally during the previous five years, and overall $21.8 \%$ of the population did not live in their hometown (National Statistical Office, 2010).

The rural-urban migration trend in Indonesia can be explained by a number of so-called push and pull factors (Wadji N. et al., 2017). While the demand for labour in urban centres is the main pull factor for people to move from rural to urban area, Tirtosudarmo (2009), Susanti and Damayanti (2015), and Sukamdi and Mujahid (2015) summarize the main push factors of internal migration in Indonesia as being the decrease of job availability in agricultural sectors, working matters, a desire to rejoin family members, marriage, the search for better economic opportunities, and access to education.

In Thailand, according to Amere et al. (2012), the lack of employment in rural areas, following family and educational opportunities are push factors which have driven people to migrate to urban 
areas. Wongchai et al. (2012) reported that the search for better job opportunities instead of farming is a factor that significantly affects the migration of farmers in northern Thailand.

One of the important changes in internal population movements in Indonesia and Thailand have been the rise in the participation of women in migration streams that were previously dominated by men. According to Sukamdi and Mujahid (2015), there are more female migrants in Indonesia then male migrants among married, divorced and widowed migrants, particularly of younger groups (15-34 years). The Thai Migration Survey of 2012 found that the number of women in Thailand's internal migration was lower than in other countries in Southeast Asia, including Indonesia. Notwithstanding, according to the National Statistics Office (2010) almost half of Thailand's internal migration flows were women $(47.8 \%)$. So, the increasing number of women in internal migration streams is occurring in both countries and led to a "feminisation of internal migration".

The aims of the study were to investigate the causes and effects of woman rural-urban migration amongst female street food vendors in Tangerang, Indonesia, and Hat Yai, Thailand, and to compare the situation in both countries. These cities had high inflows of rural-urban migrants over the past decades: Tangerang in the province of Banten, Java, Indonesia, and Hat Yai in the Songkhla province, South Thailand. Since the early 2000s, both cities are a prominent destination for rural migrants, either for short or long-term migration. Tangerang and Hat Yai grew into central urban settlements along the massive development of industries, tourism, and trades.

The research was conducted in the end of 2017 and beginning of 2018. A standardized questionnaire with socio-economic data, pattern and process of migration, history of business activities, actual situation and economic impact, opportunities and problems were conducted as well as biographical interviews. Interviewers filled the questionnaires in the local languages and recorded 20 oral biographical interviews (14 in Tangerang, 6 in Hat Yai), which were made on the basis of guidelines. Afterwards they were transcribed. Some findings of them about the causes and effects of the rural-urban migration are presented following.

\section{Research results and discussion}

Approximately a double number of women had participated in Tangerang (200) in comparison to Hat Yai (96). 175 of the Indonesian females and 64 of the Thai females were married,. The agegroups of 20 to 50 years old-women made up the dominant group with $72.5 \%$ in Tangerang and $76.1 \%$ in Hat Yai. The average respondents' age was higher in Hat Yai (Table 1).

Female migrants' age structure, in \%

\begin{tabular}{|l|c|c|c|}
\hline $\begin{array}{c}\text { Age-groups } \\
\text { years }\end{array}$ & $\begin{array}{c}\text { Tangerang, } \\
\mathbf{n = 2 0 0}\end{array}$ & $\begin{array}{c}\text { Hat Yai, } \\
\mathbf{n = 9 6}\end{array}$ & $\begin{array}{c}\text { Total, } \\
\mathbf{n = 2 9 6}\end{array}$ \\
\hline$<\mathbf{2 0}$ & 0.5 & 1.0 & 2.0 \\
\hline $\mathbf{2 1}-\mathbf{3 0}$ & 14.5 & 24.0 & 17.6 \\
\hline $\mathbf{3 1}-\mathbf{4 0}$ & 28.5 & 32.3 & 29.7 \\
\hline $\mathbf{4 1}-\mathbf{5 0}$ & 29.5 & 19.8 & 26.4 \\
\hline $\mathbf{5 1}-\mathbf{6 0}$ & 19.5 & 15.6 & 18.2 \\
\hline $\mathbf{>} \mathbf{6 0}$ & 5.5 & 7.3 & 6.1 \\
\hline Total & 100.0 & 100.0 & 100.0 \\
\hline Mean $\mathbf{5}$ SD & $42.58 \pm$ & $40.35 \pm$ & $41.86 \pm$ \\
& 11.31 & 12.31 & 11.67 \\
\hline
\end{tabular}

Source: Field work conducted in 2017-2018, authors' compilation 
In Tangerang, most women came from certain rural communities in the island of Java (Table 2). Nearly $38.5 \%$ migrants from Central Java travelled long distances to reach Tangerang. The improvement of transportation and communication had changed the movements. These findings could be found similar in the literature which is discussed by Deshingkar (2006) and Sukamdi and Mujahid (2015). Deshingkar (2006) mentioned that rural-urban migrants cover greater distances, often travelling to different states/regions than rural-rural movements with short distances. Sukamdi and Mujahid (2015) showed that long-distance migration in Indonesia increased between the 1990s and 2000s, which was driven by faster inter-provincial transportation linkages. The research also indicated that the number of short-distance migrations declined.

Table 2

\section{Places of origin of Tangerang's migrants, $\mathbf{n}=\mathbf{2 0 0}$}

\begin{tabular}{|l|c|c|}
\hline \multicolumn{1}{|c|}{ Provinces } & Frequency & Percent (\%) \\
\hline Central Java & 77 & 38.5 \\
\hline West Java & 47 & 23.5 \\
\hline Sumatra & 21 & 10.5 \\
\hline East Java & 20 & 10.0 \\
\hline Jakarta & 16 & 8.0 \\
\hline Banten & 10 & 5.0 \\
\hline Kalimantan & 5 & 2.5 \\
\hline Yogyakarta & 3 & 1.5 \\
\hline Others & 1 & 0.5 \\
\hline Total & 200 & 100.0 \\
\hline
\end{tabular}

Source: Field work conducted 2017-2018, authors' compilation

In Hat Yai, short distance migration dominated. Half of the in-migrants to Hat Yai reported that they were born in Songkhla province, while $11.5 \%, 5.2 \%$, and $4.2 \%$ respectively came from Pattani, Patthalung and Satun (Table 3). This is in line with the results from Jampaklay et al. (2017), which states that in Southern Thailand the migration movement is relatively close to the rural areas in shorter distances. Short distances and ease transportation are the main pull factors for rising of rural-urban migrant in Hat Yai areas.

Places of origin of Hat Yai's migrants, $n=96$

\begin{tabular}{|l|c|c|}
\hline \multicolumn{1}{|c|}{ Provinces } & Frequency & Percent (\%) \\
\hline Songkla & 48 & 50.0 \\
\hline Others & 13 & 13.5 \\
\hline Pattani & 11 & 11.5 \\
\hline Nakhon Si Thammarat & 7 & 7.3 \\
\hline Patthalung & 5 & 5.2 \\
\hline Narathiwat & 4 & 4.2 \\
\hline Satun & 4 & 4.2 \\
\hline Bangkok & 2 & 2.1 \\
\hline Yala & 2 & 2.1 \\
\hline Total & 96 & 100.0 \\
\hline
\end{tabular}

Source: Field work conducted 2017-2018, authors' compilation 
In terms of migration duration, a high proportion of the migrants had long settled in both study areas, with a higher average in Tangerang with $16.8 \%$ compared with $14.8 \%$ in Hat Yai.

The majority of the migrants came to Tangerang more than 20 years ago $(33.5 \%)$, to Hat Yai with $27.4 \%$. The shorter migration between one and five years has the second highest percentage in Hat Yai (24.2 \%) compared with $23.5 \%$ between six and ten years in Tangerang (Table 4).

Table 4

\section{Start of migration, in \%}

\begin{tabular}{|l|c|c|}
\hline Years & $\begin{array}{c}\text { Tangerang } \\
\mathbf{n = 2 0 0}\end{array}$ & $\begin{array}{c}\text { HatYai } \\
\mathbf{n = 9 1}\end{array}$ \\
\hline$<\mathbf{1}$ & 4.0 & 3.3 \\
\hline $\mathbf{1 - 5}$ & 9.0 & 24.2 \\
\hline $\mathbf{6 - 1 0}$ & 23.5 & 15.4 \\
\hline $\mathbf{1 1 - 1 5}$ & 13.0 & 15.4 \\
\hline $\mathbf{1 6 - 2 0}$ & 17.0 & 14.3 \\
\hline $\mathbf{> 2 0}$ & 33.5 & 27.4 \\
\hline Total & 100.0 & 100.0 \\
\hline
\end{tabular}

Source: Field work conducted 2017-2018, authors' compilation

In Hat Yai, more than half $(53.8 \%)$ of the respondents migrated on their own decision. For $19,8 \%$, the husbands were dominant for migrating decision. Relatives, parents and friends were decision makers for the residual women. In contrast, in Tangerang the husbands were decision makers in $48.5 \%$ of cases. Only $26 \%$ of respondents had left their place of origin or previous place of residence on their own decision (Table 5).

Table 5

Decision makers for migration, in \%

\begin{tabular}{|l|c|c|}
\hline Who made the decision to migrate? & $\begin{array}{c}\text { Tangerang } \\
\mathbf{n = 2 0 0}\end{array}$ & $\begin{array}{c}\text { Hat Yai } \\
\mathbf{n = 9 1}\end{array}$ \\
\hline Self-determined & 26.0 & 53.8 \\
\hline Relatives & 14.5 & 12.1 \\
\hline Parents & 7.0 & 6.6 \\
\hline Friends & 4.0 & 4.4 \\
\hline Husband & 48.5 & 19.8 \\
\hline Spouse & - & 3.3 \\
\hline Total & 100.0 & 100.0 \\
\hline
\end{tabular}

Source: Field work conducted 2017-2018, authors' compilation

Bell (2013) found that roughly nine-in-ten or more (93\%) of Indonesian Muslim women said that wives must obey their husbands. Therefore, many women migrants, after they had married, followed their husbands, including for migration decision. Initially, women in Tangerang did not migrate to Tangerang as their first move from their place of origin, but to other destinations, such as Jakarta or Bandung. Tangerang became the last move for migrants when their husbands chose to migrate to Tangerang for helping the family. In cases of married women, the influence of the husband on their decision was predominant. If the husband disapproved of the migration, their wives less likely tended to migrate or stop migrating. Nearly half of the interviewed women migrants in Tangerang claimed that the decision to move to urban centres was mostly made by their husband. About $26 \%$ of respondents in Tangerang had left their place of origin on their own personal decision, which was relatively low compared to those who moved based on their husband's decision. Some women may 
have decided to move on their own to Tangerang because they were involved in occupations and got a job offer from their relatives, which led them to migrate to Tangerang.

In Hat Yai, even though the survey indicated that the women decided they wanted to migrate by themselves, their decision was not totally independent. In the interviews, most of them reported the decision to migrate on their own with the consent of their parents before migration and in some cases, parents even encouraged their children to migrate and sometimes helped to fund the transportation costs. This decision mainly occurred when migration from the village was primarily motivated by the need to ensure the survival of rural households.

In order to make the final decision to move to any area, migrants often got to know the place in advance through many sources of information. The available sources played an important role in the process of migration. Table 6 shows that a higher percentage, $46.4 \%$ in Tangerang and $55.6 \%$ in Hat Yai respectively, had obtained information about the conditions of the destination through friends and relatives.

Table 6

Sources of information to migrate, in \%

\begin{tabular}{|l|c|c|}
\hline \multicolumn{1}{|c|}{ Sources } & $\begin{array}{c}\text { Tangerang } \\
\mathbf{n = 2 0 0}\end{array}$ & $\begin{array}{c}\text { Hat Yai } \\
\mathbf{n = 9 1}\end{array}$ \\
\hline Friends and relatives & 46.4 & 55.6 \\
\hline Mass media & 3.3 & 6.9 \\
\hline Previous visit & 18.6 & 12.5 \\
\hline Family members & 30.1 & 25.0 \\
\hline Others & 1.6 & - \\
\hline Total & 100.0 & 100.0 \\
\hline
\end{tabular}

Source: Field work conducted 2017-2018, authors' compilation

Between both study areas, similarities and differences could be seen in the reasons for migration. Push factors for migration were poverty and unemployment and insufficient farming income. They were mentioned in similar frequency in both study areas, but better prospects dominated in Hat Yai (50.4\%) compared to Tangerang (29.1\%). To find jobs and migration opportunities for other family members and married women following husband were the indicators of pull factors $(28.0 \%$ in Tangerang, $15.8 \%$ in Hat Yai) (Table 7).

Reasons for migration, in \%, multiple answers possible

\begin{tabular}{|l|c|c|}
\hline \multicolumn{1}{|c|}{ Reasons } & $\begin{array}{c}\text { Tangerang } \\
\mathbf{n = 2 0 0}\end{array}$ & $\begin{array}{c}\text { Hat Yai } \\
\mathbf{n = 9 1}\end{array}$ \\
\hline Poverty and unemployment & 14.6 & 13.9 \\
\hline Better prospects & 29.1 & 50.4 \\
\hline $\begin{array}{l}\text { To find jobs and migration opportunities for other family } \\
\text { members }\end{array}$ & 18.5 & 12.9 \\
\hline Insufficient farming income & 2.4 & 5.0 \\
\hline Married and followed husband & 28.0 & 15.8 \\
\hline Others & 7.5 & 2.0 \\
\hline Total & 100.0 & 100.0 \\
\hline
\end{tabular}

Source: Field work conducted 2017-2018, authors' compilation

Several studies reported that migration varies depending on economic and non-economic factors (Lewis G., 1982; Todaro M. P., 1997). All factors for migration are included in two broad classifications as push and pull factors (World Bank, 2009). The results have revealed that poverty, 
job searching, insufficient farming income and lack of education facilities were the main push factors for out-migration, while at the place of destination, the availability of employment, better opportunity, married and followed husband and search for better education were the main pull factors behind migration. Education of the migrants and their occupation at the place of origin were related with the push factors of the migrants. Poverty was found to be the main push factor for illiterates and moderately educated migrants, job searching was the main push factor among the migrants having graduate-level education or higher one. To conclude, urban pull factors are more contributing to rural-urban migration than push factors.

Previous studies had also shown that most people moved out of their home of origin for economic reasons. Wajdi et al. (2017) found that one of the economic factors for inter-regional migration in Indonesia was likely related to search for better prospect opportunities. This study, therefore, lent support to the UNESCO research on internal migration in Southeast Asia. UNESCO (2017) found that the majority of migrants in Southeast Asia considered that getting employment was the main motivation for migration.

The survey results of this study also confirmed the theories by Todaro (1997). He stated that rural-urban migration nowadays to large extent can be explained by economic factors than noneconomic factors. In Indonesia, rural-urban migration also most often took place as a response to economic factors rather than non-economic factors (Susanti \& Damayanti, 2015). Susanti and Damyanti explained that working matters were the major reasons for migration of the majority of people.

The results of a fewer number of participants show the support of families and relatives through remittances. The main recipients of remittances were the parents, $53.8 \%$ in Tangerang and $53.1 \%$ in Hat Yai respectively, followed by women's children (26.4\% and $25 \%$ ) (Table 8 ).

Table 8

\section{Recipients of remittances, in \%, multiple answers possible}

\begin{tabular}{|l|c|c|}
\hline Recipients of migrants' remittances & $\begin{array}{c}\text { Tangerang } \\
\mathbf{n}=\mathbf{9 6}\end{array}$ & $\begin{array}{c}\text { Hat Yai } \\
\mathbf{n = 1 8}\end{array}$ \\
\hline Parents & 53.8 & 53.1 \\
\hline Children & 26.4 & 25.0 \\
\hline Relatives & 19.8 & 21.9 \\
\hline Total & 100.0 & 100.0 \\
\hline
\end{tabular}

Source: Field work conducted 2017-2018, authors' compilation

The interviews show that women in Hat Yai visited their hometown more regularly hence the shortfall in the proportion of cash remitted to the place of origin. In respect of the amount of remittances, the difference per transfer at present and when the vendors started the business in Hat Yai and Tangerang is meaningful. As noted, the end use of remittance for the receiving household is related with basic necessities such as food and human capital (education). Remittances are a positive outcome of migration. Remittances, the portion of a migrant worker's earnings sent back from the destination of employment to the origin of the migrant, play a central role in the livelihood of many households in rural areas. Amuedo-Dorantes et al. (2007); Quartey and Blankson (2004) and Adger et al. (2002) stated that migrant remittances have played an important role in the economic development, social resilience and the improvement of household welfare in many developing countries. The present evidence was expected in the view of the fact that most women in Tangerang and Hat Yai still had an emotional connection to their place of origin by entrusting a part of their 
income to their parents, both for daily needs and other necessities. These findings are rather similar to those suggested by Ranathunga (2011). He found that in Sri Lanka, the majority of the ruralurban migrants remitted monthly their money to their home places where nearly one-third of the remittances were used for the investment purpose of education and farm work. In line with the results before, in Lesotho, the majority of households received remittances frequently and regularly at least once a month from their family in urban areas (Crush J. B. et al., 2010). Adaawen and Owusu (2013) stated almost four in five of the migrants in Ghana remitted money in less than three months interval.

$60.8 \%$ of 96 women in Tangerang were likely to send money monthly, around $10.2 \%$ three times per year, and $7.2 \%$ two times a year, while the majority $(77.8 \%)$ of women in Hat Yai sent their remittances to home monthly and about $16.7 \%$ six times a year (Table 9). The amount of money sent to home varies among them. The actual remittances were a bit higher than when women had just opened their businesses. In Hat Yai, only 18 women answered on the question about the amount. The average amount of remittances when the vendors had started the business was lower.

Table 9

Frequency of remittances, in \%

\begin{tabular}{|c|c|c|}
\hline Frequency of remittances & $\begin{array}{c}\text { Tangerang } \\
n=96\end{array}$ & $\begin{array}{c}\text { Hat Yai } \\
n=18\end{array}$ \\
\hline$>12$ times a year & 5.2 & - \\
\hline Monthly & 60.8 & 77.8 \\
\hline 6 times a year & 6.2 & 16.7 \\
\hline 4 times a year & 5.2 & - \\
\hline 3 times a year & 10.2 & 5.5 \\
\hline 2 times a year & 7.2 & - \\
\hline Once a year & 5.2 & - \\
\hline Total & 100.0 & 100.0 \\
\hline
\end{tabular}

\section{Conclusions, proposals, recommendations}

Rural-urban movements from poor rural areas to rich urban areas have been the dominant form of migration. There has been a sharp increase in rural-urban migration in recent years, including Tangerang and Hat Yai. A high proportion of women street food vendors have settled for a number of years but they are closely connected to their origin and families. In Hat Yai, the connection is more intensive through the short distances than in Tangerang. In Tangerang, a stronger influence of husbands on the migration decision was found. Many women support the families at home with remittances. But mostly, they will not come back to their places of origin.

The migration of women had an implication on the agricultural production because the youthful labour force, which were supposed to cultivate the farmland, migrate to the urban centres. As a result, agricultural production in rural areas can be hampered and adversely affected because of the dominance of labour by old ages in rural areas.

\section{Bibliography}

1. Adaawen, S.A., Owusu, B. (2013). North-South Migration and Remittances in Ghana. African Review of Economics and Finance, Volume 5, No.1, pp. 29-35.

2. Adger, W.N., Mick Kelly, P., Winkels, A., Huy, L.Q., Locke, C. (2002). Migration, Remittances, Livelihood Trajectories, and Social Resilience. Royal Swedish Academy of Sciences. Ambio Volume 31 No. 4, pp. 358366. 
3. Amare M., Hohfeld L., Jitsuchon S., Waibel, H. (2012). Rural-urban Migration and Employment Quality: A Case Study from Thailand. Asian Development Review, Volume 40, pp. 78-84.

4. Amuedo-Dorantes, C. Pozo, S., Vargas-Silva, C. (2007). Remittances and the Macroeconomy. The Case of Small Island Developing States. Research Paper No. 2007/22, United Nations University, World Institute for Development Economics Research (WIDER).

5. Ananta, A., Arifin, E.N. (2014). Emerging Patterns of Indonesia's International Migration. Malaysian Journal of Economic Studies 51(1), pp. 29-41.

6. Bell, J. (2013). The World's Muslims: Religion, Politics and Society. Pew Research Center's Forum on Religion \& Public Life, Washington DC.

7. Crush J., Dodson B., Gay J., Green T., Leduka C. (2010). Migration, Remittances and 'Development' in Lesotho. SAMP Migration Policy Series No. 52, Cape Town.

8. Deshingkar, P. (2006). Internal Migration, Poverty and Development in Asia. Paper: Promoting Growth, Ending Poverty Asia 2015.

9. Hossain, I. (2001). A Rapid Situation Assessment of Migration and Remittances and their Impacts on Food Security, Agriculture and Rural Development. FAO, Rome

10. Jampaklay, A., Ford, K., Chamratrithirong, A. (2017). How does Unrest Affect Migration? Evidence from the Three Southernmost Provinces of Thailand. Demographic Research, Volume 37, Article 3, pp. 25-52.

11. Lewis, G. (1982). Human Migration: A Geographical Perspective. London: Croom Helm Ltd.

12. Murrugarra, E., Larrison, J., Sasin, M. (2011). Migration and Poverty: Toward Better Opportunities for the Poor. The International Bank for Reconstruction and Development/The World Bank, Washington DC.

13. National Statistical Office. (2010). The Population and Housing Census 2010. National Statistical Office of Thailand, Bangkok.

14. Quartey, P. and T. Blankson (2004). Do Migrant Remittances Minimize the Impact of Macro Volatility on the Poor in Ghana? A Proposal for The African Economic Consortium (AERC).

15. Ranathunga, S. (2011). Impact of Rural to Urban Labour Migration and the Remittances on Sending Household Welfare: A Sri Lankan Case Study. MPRA Paper No. 35943, posted 27 January 2012.

16. Siddiqui, T. (2003). Migration as a Livelihood Strategy for the Poor: The Bangladesh Case. Paper presented at Regional Conference on Migration Development Pro-Poor Policy Choices in Asia, Dhaka, Bangladesh.

17. Sukamdi, Mujahid, G. (2015). UNFPA Indonesia Monograph Series: No.3, Internal Migration in Indonesia. UNFPA Indonesia Monograph Series, Jakarta. https://indonesia.unfpa.org/en/publications/monograph-series-no-3-internal-migration-indonesia. Access: 09.10.2018.

18. Susanti, H. and Damayanti, A. (2015). Internal Migration in Indonesia: Duration and Factors. Working paper. Department of Economics, Faculty of Economics and Business, University of Indonesia, Depok.

19. Tirtosudarmo, R. (2009). Mobility and Human Development in Indonesia. United Nations Development Programme Human Development Reports, Research Paper 19, Jakarta.

20. Todaro M. P. (1997). Urbanization, Unemployment and Migration in Africa: Theory and Policy. Paper prepared for Reviewing Social and Economic Progress in Africa No 104, Macmillan.

21. Wajdi, N., Mulder, C.H., Adioetomo, S. M. (2017). Inter-regional migration in Indonesia: a micro approach. Journal of Population Research, Volume 34, pp. 253-277.

22. Wongchai, A., Yang Y.-C., Peng K.-C. (2012). Factors Affecting Rural-Urban Migration of Northern Thai Farmers. Journal of International Cooperation 7 (1), pp. 91-106.

23. World Bank. (2009). World Development Report 2009: Reshaping Economic Geography. World Bank, Washington DC.

24. UNESCO (2017). Migration, Free Movement and Regional Integration. UNESCO and UNU-CRIS, Brugge, Belgium. 